\title{
ANALISIS DAMPAK ELECTRONIC DATA PROCESSING DALAM PROSES AUDIT INTERNAL BAGI AUDITOR INTERNAL PT BANK SULUTGO
}

\author{
Reynaldi R. Mandagi ${ }^{1}$, Sifrid S. Pangemanan ${ }^{2}$, Heince R. N. Wokas ${ }^{3}$ \\ 1,2,3 Jurusan Akuntansi, Fakultas Ekonomi dan Bisnis, Universitas Sam Ratulangi, Jl. Kampus Bahu, Manado, \\ 95115, Indonesia \\ E-mail : aldimandagi@yahoo.co.id
}

\begin{abstract}
Electronic Data Processing (EDP) is the use of automated methods for commercial data processing. As part of information technology, EDP performs repeated data processing of similar data with relatively simple forms of processing. Standar Profesional Akuntan Publik (SPAP) also emphasizes the need for auditor's understanding in examining a computer-based accounting system. This technique in Indonesian is known as Teknik Audit Berbantuan Komputer (TABK) or Computer Assisted Audit Techniques (CAATs) set forth in PSA No. 59 on Computer Assisted Auditing Techniques (SA Section 327). The method used in this study is a qualitative descriptive method by collecting and analyzing data and then drawing conclusions. The results obtained show that young auditors are more adaptable to the development of information technology, especially in conducting computerized internal audit and control. Impacts given in the audit process include increasing independence for internal auditors, providing accuracy and speed in managing data, and producing output from more accurate audit data processing. Impact on internal controls is to make the auditor perform internal control procedures after applying the EDP in the audit process to minimize the possibility of process errors, secure the program and data, and control the audit process to ensure that the audit has been properly implemented. The audit process using EDP is faced with several risks such as errors in data processing caused by human error, data loss caused by computer problems, and the computer used is exposed to the virus.
\end{abstract}

Keywords : Analysis, Electronic Data Processing, Internal Audit

\section{PENDAHULUAN}

Pada era modern saat ini ilmu pengetahuan teknologi informasi menjadi salah satu yang memegang kendali dalam setiap aktivitas manusia sehari-hari, dimana pun dan kapanpun setiap orang membutuhkan teknologi untuk mendapatkan informasi dan berkomunikasi. Dengan adanya teknologi informasi mempermudah seseorang menyelesaikan pekerjaannya, bahkan pekerjaan yang membutuhkan waktu dan tenaga yang lebih dapat diselesaikan sendiri dalam waktu yang singkat. Oleh karena itu penguasaan teknologi informasi sangatlah penting dan bahkan menjadi salah satu syarat dari sebuah perusahaan untuk calon pegawai baru yang ingin melamar di perusahaan tersebut. Jaringan komputer memberikan jaminan terhadap hak akses dari para pemakai dalam perusahaan tersebut dengan memberikan batasan akses bagi setiap pemakai komputer tersebut. Data-data yang di input dalam komputer dapat saling terintegrasi mulai dari data penjualan, pembelian, persediaan, keuangan, dan data lainnya. Jaringan komputer membantu menghubungkan datadata tersebut walau berasal dari tempat yang berbeda. Pesatnya kemajuan teknologi menyebabkan meningkatnya kebutuhan perusahaan akan penerapan sistem akuntansi yang berbasis komputer, yang dikenal dengan istilah Electronic Data Processing (EDP).

PT Bank SulutGo dalam melakukan kegiatan operasionalnya melayani para nasabah yang melakukan transaksi-transaksi yang terjadi setiap hari berjumlah ratusan bahkan ribuan sehingga bantuan teknologi menjadi sangat penting dalam menunjang aktivitas perusahaan. 
Setiap transaksi tersebut di input ke dalam software berbasis web yang terhubung ke server. Selain di input oleh para karyawan, transaksi yang dilakukan melalui internet banking, sms banking, dan ATM akan langsung terekam oleh sistem tersebut. Walaupun perusahaan telah menggunakan teknologi untuk membantu opersionalnya namun tingkat kecurangan dapat terjadi dan berdasarkan Peraturan Bank Indonesia No.1/6/PBI/1999 tanggal 20 September 1999 tentang Penugasan Direktur Kepatuhan (Compliance Director) dan Penerapan Standar Pelaksanaan Fungsi Audit Internal Bank Umum, sehingga PT Bank SulutGo melakukan audit internal yang dilaksanakan oleh Satuan Kerja Audit Internal (SKAI) untuk lebih berfungsinya pengendalian internal pada setiap aktivitas operasional PT Bank SulutGo. Dalam melakukan audit, para auditor internal harus memahami teknologi dan sistem informasi yang digunakan oleh PT Bank SulutGo untuk membantu auditor melaksanakan proses audit, karena transaksi yang terjadi sangat banyak juga PT Bank SulutGo sudah memiliki puluhan kantor cabang dan cabang pembantu maka diperlukan bantuan teknologi untuk membantu proses audit.

\section{TINJAUAN PUSTAKA}

Akuntansi. Menurut AICPA (American Institute of Certified Public Accountants) yang dikutip oleh Madcoms (2015:2) mendefinisikan akuntansi sebagai seni dalam mencatat, mengelompokan dan mengikhtisarkan berdasarkan cara yang berarti kemudian dinyatakan dengan satuan uang dari semua jenis transaksi bersifat komersial lalu memperkirakan hasilnya. Fungsi akuntansi adalah berkaitan dengan mencatat transaksi-transaksi pada sebuah perusahaan atau entitas ekonomi yang lain, lalu menyusun laporan keuangan secara berkala dari catatan transaksi tersebut (Mardiasmo, 2014:5).

Akuntansi keuangan. Akuntansi keuangan merupakan salah satu cabang dari akuntansi yang mencatat, mengklasifikasikan, meringkas, menginterpretasikan, dan mengomunikasikan informasi keuangan pada suatu bisnis. Informasi akuntansi pada dasarnya menyajikan informasi ekonomi kepada banyak pihak yang memerlukan. Adapun pihak yang memerlukan informasi akuntansi terbagi ke dalam 2 (dua) jenis yaitu pihak internal dan pihak eksternal. Pengguna eksternal dari informasi akuntansi adalah investor, kreditor, pelanggan, dan pemerintah. Para pengguna ini tidak secara langsung terlibat dalam mengatur dan mengoperasikan bisnis. Area akuntansi yang menyediakan informasi akuntansi bagi pengguna eksternal disebut sebagai akuntansi keuangan (Warren, 2017:6).

Pengertian Audit. Audit merupakan sebuah pemeriksaan yang dikerjakan secara rinci dan teratur menurut sistem yang dikerjakan oleh pihak independen dan berkompetensi terhadap laporan keuangan yang dibuat oleh pihak pimpinan yang bertanggungjawab bersama dengan unsur-unsur yang ada pada prinsip akuntansi yang bertujuan untuk bisa memberikan pendapat mengenai kewajaran laporan keuangan sesuai dengan prinsip akuntansi. Keterangan-keterangan berupa bukti dan standar yang ditetapkan dibutuhkan dalam porses audit (Seputra, 2013:3).

Audit Internal. Audit yang dikerjakan oleh auditor internal pada umumnya lebih rinci daripada audit yang dikerjakan oleh KAP. Auditor internal tidak menyatakan pendapat terhadap tingkat kewajaran dari laporan keuangan, auditor internal juga dianggap tidak independen oleh pihak eksternal perusahaan karena merupakan orang dalam perusahaan tersebut (Seputra, 2013:13).

Standar Pelaporan. Ikatan Bankir Indonesia (2014:569) menyatakan bahwa auditor internal wajib membuat laporan tertulis dari semua hasil auditnya. Proses penyusunan laporan harus dilewati dengan berisikan materi yang lengkap dan harus memenuhi standar pelaporan.

Pengendalian Internal. Pengendalian internal adalah sekumpulan kebijakan dan prosedur dalam melindungi aset perusahaan dari semua tindakan penyalahgunaan, memberikan jaminan keakuratan informasi akuntansi perusahaan, dan memberikan kepastian bahwa semua aturan hukum/undang-undang serta keputusan manajemen telah dipatuhi dan 
dijalankan sebagaimana mestinya oleh semua karyawan perusahaan (Hery, 2013:159). Menurut Hadi (2010:3) pengendalian internal berdasarkan hasil penelitian yang dikerjakan oleh COSO memiliki unsur-unsur pengendalian internal, yaitu:
1. Control environment
2. Risk assessment
3. Control activities
4. Information and communication
5. Monitoring activities

Pengertian, Jenis, dan Bentuk EDP Audit. EDP auditing adalah suatu kegiatan mengumpulkan dan menilai bukti dalam menentukan kemampuan perlindungan aset pada suatu sistem komputer, integritas data dipertahankan, tujuan organisasi dapat tercapai dengan efektif, dan sumber daya yang digunakan lebih efisien (Seputra, 2013:248). Dalam mengaudit laporan keuangan klien yang disusun menggunakan sistem komputer, auditor dapat melakukan tiga cara yang bisa dikerjakan oleh auditor, yaitu:

1. Auditing Around The Computer

2. Auditing With The Computer

3. Auditing Through The Computer

Kebutuhan dari setiap perusahaan dapat ditentukan berdasarkan bentuk EDP audit yang dimiliki, seperti:

1. Sebagai sokongan bagi satuan audit

2. Sebagai bentuk pemeriksaan kinerja

3. Sebagai bentuk pemeriksaan atas pusat jasa komputer

\section{Penelitian Terdahulu}

1. Amanda (2016) dengan judul Dampak Electronic Data Processing Pada Proses Auditing Dan Pengendalian Internal Bank Bri Wilayah Surabaya. Hasil penelitian menunjukkan Auditor internal mampu memberikan definisi dan memberikan penjelasan tentang EDP berdasarkan pemahaman mereka, fungsi pengendalian dan kendala dalam mengaudit, sehingga tingkat pemahaman eksploratoris dapat dicapai oleh auditor internal. Penggunaan EDP dalam mengaudit dan pengendalian internal mampu dijelaskan oleh auditor internal. Para informan dalam hal ini para auditor internal mampu mencapai tingkat ekstrapolasi. Namun pada satu auditor merasa dalam pengerjaannya tidak mendapat risiko atas pelaksanaan EDP audit.

2. Jasmat (2010) dengan judul Analisis Penerapan Electronic Data Processing (EDP) Dalam Sistem Informasi Akuntansi Pada Pt. Citra Riau Sarana Kabupaten Kuantan Singingi. Hasil penelitian menunjukkan proses pengolahan data bagian EDP menggunakan Batch Processing dimana data transaksi yang ada di tumpuk kemudian di olah secara bersamaan semua transaksi, komputer hanya merekam data jurnal yang di input. Selain itu data yang berbentuk dokumen di kirim adalah laporan keuangan yang menyangkut berbagai laporan kas, inventory, realisasi anggaran, laporan gaji karyawan, laporan TBM (tanaman belum menghasilkan), TSM (tanaman sudah menghasilkan) dan tingkat penjualan CPO (Crued Palm Oil).

\section{METODE PENELITIAN}

Jenis Penelitian. Penelitian yang dilakukan bertujuan untuk mengetahui sejauh mana pemahaman auditor PT Bank SulutGo tentang EDP dalam proses audit dan mengetahui dampak serta risiko dalam menjalankan pengendalian internal saat melakukan proses audit komputerisasi.

Tempat dan Waktu Penelitian. Penelitian ini dilakukan pada PT Bank SulutGo, dengan alamat Jalan Sam Ratulangi Nomor 9, Wenang Utara, Kecamatan Wenang, Kota Manado, Sulawesi Utara, 95111. Penelitian dilaksanakan pada bulan Mei sampai bulan Juni 2018. 
Jenis, Sumber, dan Metode Pengumpulan Data

Jenis Data. Penulis meneliti dampak EDP dalam proses audit yang dilakukan oleh auditor internal PT Bank SulutGo dengan mengumpulkan data dari wawancara dan observasi. Kemudian penulis melakukan analisis hasil wawancara yang didapat dari objek penelitian.

Sumber Data. Sumber data yang digunakan dalam meneliti adalah data primer yang langsung diperoleh di lapangan, berupa hasil wawancara, kebijakan-kebijakan perusahaan tentang penggunaan komputer dan program aplikasinya, serta sistem dan pengolahan data yang langsung di peroleh dari SKAI.

\section{Metode Pengumpulan Data}

1. Wawancara. Pertanyaan wawancara yang akan ditanyakan adalah sebagai berikut: (a) Pertanyaan tentang latar belakang narasumber; (b) Pertanyaan tentang informasi perusahaan PT Bank SulutGo; (c) Pertanyaan pendapat auditor tentang EDP dalam audit; (d) Pertanyaan mengenai dampak penggunaan EDP dalam audit; dan (e) Pertanyaan mengenai pemahaman risiko.

2. Dokumentasi. Data yang diperoleh dari proses audit internal menggunakan komputer yang dilakukan oleh auditor internal.

3. Teknik Kepustakaan. Referensi tentang perusahaan baik dari buku maupun data-data yang tersimpan dikomputer perusahaan.

\section{Metode dan Proses Analisis}

Metode Analisis. Metode deskriptif adalah metode yang dipakai dalam melaksanakn penelitian ini. Metode deskriptif menurut Sugiyono (2014:22) adalah metode yang dipakai untuk melukiskan atau melakukan analisis sebuah hasil penelitian namun tidak untuk menghasilkan ikhtisar yang lebih luas.

Proses Analisis. Adapun langkah-langkah yang ditempuh dalam menganalisis data yang berkaitan dengan proses audit berbantuan komputer sebagai berikut :

1. Mewawancarai auditor internal PT Bank SulutGo untuk mendapatkan data yang dibutuhkan dalam penelitian ini.

2. Menganalisis hasil wawancara mengenai pemahaman auditor internal tentang EDP audit, menganalisis dampak EDP dalam proses audit internal dan prosedur pengendalian internal pada EDP, serta menganalisis risiko dan pencegahan pada proses audit internal.

3. Menyimpulkan bagaimana pendapat auditor, dampak EDP pada audit dan pengendalian internal, dan risiko yang muncul saat menggunakan EDP.

4. Menyarankan suatu masukan dan memberikan rekomendasi.

\section{HASIL PENELITIAN DAN PEMBAHASAN}

\subsection{Hasil Penelitian}

Pemahaman Auditor Internal PT Bank SulutGo Tentang Electronic Data

Processing Dalam Proses Audit Internal. Berdasarkan hasil wawancara yang dilakukan dengan informan, audit manual dengan audit menggunakan EDP pada dasarnya keduanya mengumplkan data/bukti lalu menilai data/bukti untuk memastikan dan memberitahukan keselarasan kegiatan operasional yang dijalankan oleh bank dan kriteria yang telah ditetapkan. EDP dalam proses audit menggunakan program untuk melakukan pengelolaan data audit dengan berbantuan komputer. Metode yang dipakai, yaitu:

1. Audit around the computer.

2. Audit with the computer.

3. Audit through the computer

Menurut informan penggunaan sistem/software untuk mengelola data output yang dihasilkan dari sistem bank yang digunakan untuk kepentingan proses audit sangat membantu bagi auditor untuk mengelolah data dan menghasilkan output data yang akurat. Berdasarkan pengamatan yang dilakukan oleh penulis saat melakukan penelitian di Bank SulutGo, auditor 
yang melakukan proses audit menggunakan sistem komputer sebagian besar adalah auditor berusia muda.

Dampak Yang Dihasilkan Setelah Menggunakan Electronic Data Processing Dalam Proses Audit Internal. Penggunaan sistem/software dalam membantu proses audit menurut informan memberikan manfaat yang sangat baik bagi auditor dalam mengaudit, namun penggunaan sistem/software tersebut tentu saja memiliki kelebihan dan kekurangan.

Kelebihan Dan Kekurangan Dalam Proses Audit Internal Menggunakan EDP. Berikut hasil wawancara dari informan tentang kelebihan dalam proses audit menggunakan EDP:

1. Memungkinkan auditor memiliki tingkat independensi yang tinggi karena proses audit hanya bisa dilakukan dan diakses oleh auditor yang memiliki hak akses.

2. Penggunaan komputer memberikan manfaat keakuratan dan kecepatan dalam proses pengolahan data sehingga proses audit lebih efektif dan efisien.

3. Memberikan hasil output yang lebih akurat setelah dilakukan pengolahan data dengan bantuan komputer.

Selain memberikan kelebihan, adapula kekurangan dari penggunaan EDP dalam proses audit:

1. Program yang akan digunakan dalam EDP umumnya berbayar dan harus diperpanjang secara berkala sehingga memerlukan pengeluaran rutin.

2. Diperlukan pengetahuan khusus untuk melaksanakan perintah-perintah untuk mengoperasikan software seperti Audit Command Language (ACL).

Berdasarkan hasil wawancara mengenai kekurangan dari penggunaan EDP dalam proses audit, peneliti menanyakan juga solusi dari kekurangan tersebut dan yang dilakukan oleh informan dalam mengatasi kekurangan, yaitu dengan melakukan penganggaran dalam pengeluaran biaya dan software yang dipilih benar-benar dapat membantu dalam mengelola data audit. Kemudian melakukan pelatihan - pelatihan penggunaan software ACL bagi auditor dalam membantu pengolahan data.

Penggunaan Pengendalian Internal. Menurut informan pengendalian internal dilaksanakan dengan tujuan untuk menciptakan kondisi yang mendukung kelancaran dan ketepatan pelaksanaan tugas dalam organisasi sesuai dengan peraturan yang berlaku dengan demikian dapat membatu manajemen/pemimpin perusahaan dalam mengendalikan kegiatan dan operasional bank agar dapat berjalan secara ekonomis, efisien dan efektif. Pengendalian internal dimaksudkan untuk memastikan kegiatan/operasional bank telah dilaksanakan sesuai dengan prosedur yang telah ditetapkan. Pengendalian internal dalam dapat dilakukan melalui:

1. Application Control untuk memastikan data dan aplikasi yang dipakai pada komputer lebih saksama, lengkap, dan tidak terlambat dalam memberikan informasi.

2. Common Control untuk menentukan data di input dan di olah dengan benar pada sebuah aplikasi untuk memberikan output yang memenuhi syarat.

Prosedur pengendalian internal dalam EDP yakni:

1. Melakukan pengendalian terhadap akses semua sumber daya yang dipakai dalam audit dari pihak yang tidak berhak dengan cara memberikan password akses terhadap penggunaan sumber daya tersebut agar tidak mudah dicuri dan hilang.

2. Melakukan pengendalian data dan prosedur pengolahan komputer, mengurangi kemungkinan process error, dan menentukan kelanjutan operasional.

3. Melakukan pengendalian input untuk memastikan kelangsungan pemrosesan data dengan cara:

a. Semua data harus disepakati dan diakui oleh manajemen.

b. Pengendalian dalam mengkonversi data agar data di input dengan benar dan pengkonversian dikerjakan dengan sahih.

c. Pelaksanaan koreksi pada data yang tidak benar.

4. Melakukan pengendalian proses dengan maksud agar memastikan pengolahan pada komputer telah dilakukan seperti yang diinginkan. 
5. Melakukan pengendalian terhadap output agar menghasilkan data yang diolah dengan benar dan memastikan bahwa hanya pihak yang berhak saja mendapat hasil pengolahan tersebut. Pengendalian output meliputi:

a. Pelaksanaan rekonsiliasi penjumlahan

b. Perbandingan dengan dokumen sumber

Risiko Dalam Melakukan Proses Audit Komputerisasi. Dalam pelaksanaan operasional bank diperhadapkan dengan risiko-risiko berhubungan dengan fungsi bank. Risiko pada pebankan dapat muncul akibat dari berkembangnya kondisi internal dan eksternal bank tersebut, dengan demikian dibutuhkan praktik tata kelola Bank yang baik (good corporate governance) serta peningkatan fungsi identification, measurement, monitoring, dan risk control Bank yang efektif supaya kegiatan yang dijalankan oleh Bank tidak menghasilkan kerugian diluar kemampuan atau dapat mengusik kelanjutan usaha Bank. Perbankan maupun otoritas pengawasan Bank akan mendapatkan manfaat dari di terapkannya management risk. Prosedur yang memadai dan uraian tentang metode mengelola risiko merupakan dasar dari penerapan manajemen risiko sehingga kegiatan usaha Bank tetap terkendali (manageable) pada batasnya serta menguntungkan pihak Bank. Dalam melaksanakan proses audit secara komputerisasi tentunya diperhadapkan dengan risiko-risiko seperti:

1. Kesalahan dalam pemrosesan data yang diakibatkan oleh human error.

2. Hilangnya data pada komputer/laptop yang diakibatkan oleh permasalahan pada komputer/laptop.

3. Komputer/laptop yang digunakan untuk pemrosesan data terkena virus.

Untuk mencegah dan menanggulangi risiko dalam proses audit komputerisasi para auditor meningkatkan kompetensi dalam menggunakan software untuk mengolah data audit, melakukan back up data pemrosesan audit secara berkala baik media penyimpanan internal maupun media penyimpanan eksternal, kemudian menginstal anti virus dan melakukan update secara berkala.

\subsection{Pembahasan}

Analisis Pemahaman Auditor Internal PT Bank SulutGo Tentang Electronic Data Processing Dalam Proses Audit Internal. Berdasarkan hasil penelitian yang dilakukan menunjukkan bahwa penggunaan EDP dalam proses audit internal yang dikerjakan oleh auditor internal Bank SulutGo pada dasarnya sama dengan audit yang dilakukan secara manual yaitu melalui proses pengumpulan data/bukti dan melakukan penilaian data/bukti tersebut untuk menentukan dan melaporkan kesesuaian antara aktivitas operasional yang dijalankan oleh Bank dan kriteria yang telah diterapkan. Pemrosesan tersebut semuanya dilakukan menggunakan perangkat komputer dengan bantuan beberapa software pengolah data, seperti Microsoft Word, Microsoft Excel, dan Audit Command Language (ACL). Metode-metode yang digunakan pada EDP audit, yaitu:

1. Audit around the computer yang merupakan pendekatan awal yang dilakukan oleh auditor untuk memastikan bahwa sampel output dari suatu sistem komputer sudah benar, maka pemrosesannya dapat diandalkan.

2. Audit with the computer, pada metode ini auditor menggunakan perangkat lunak untuk membantu menulis, menghitung, dan menganalisis.

3. Audit through the computer, dalam metode ini auditor lebih menegaskan pada proses dan mengendalikan program yang dilakukan oleh komputer.

Pada Bank SulutGo sebagian besar auditor berusia muda yang melakukan proses audit EDP karena dinilai auditor yang berusia muda lebih cepat beradaptasi dengan perkembangan teknologi informasi terutama dalam melakukan audit dan pengendalian internal terkomputerisasi. Hasil penelitian yang dilakukan oleh Yang, Lin, dan Koo (2011) 
menunjukkan bahwa kemampuan adaptasi pengendalian internal terkomputerisasi memiliki pengaruh yang signifikan terhadap efikasi pengendalian internal dan kinerja operasional.

Analisis Dampak Yang Dihasilkan Setelah Menggunakan Electronic Data Processing Dalam Proses Audit Internal. Dengan adanya penggunaan EDP dalam proses audit yang dilakukan oleh auditor internal memberikan dampak bagi auditor dalam mengaudit, namun penggunaan EDP memiliki kelebihan dan kekurangan. Berikut merupakan kelebihan menggunakan EDP dalam membantu proses audit:

1. Dengan menggunakan EDP memungkinkan auditor memiliki tingkat independensi yang tinggi. Karena software audit akan langsung menunjukkan adanya kesalahan dan dapat langsung dibaca oleh pimpinan. Data yang diolah bersifat read only sehingga menjamin orisinalitas, keamanan dan integritas data. Penelitian yang dilakukan oleh Karamoy dan Wokas (2015) memperlihatkan bahwa independensi berpengaruh signifikan dalam mendeteksi fraud pada auditor internal.

2. Penggunaan komputer memberikan manfaat keakuratan dan kecepatan dalam proses pengolahan data sehingga proses audit lebih efektif dan efisien. Data yang di analisis adalah seluruh data bukan sample.

3. Memberikan hasil output yang lebih akurat setelah dilakukan pengolahan data dengan bantuan komputer.

Berdasarkan hasil wawancara dari informan menunjukkan bahwa penggunaan EDP dalam proses audit memberikan manfaat yang sangat baik sehingga auditor memiliki tingkat independensi yang tinggi, lebih akurat dan lebih cepat dalam mengolah data sehingga proses audit dapat diselesaikan dalam waktu beberapa hari saja, dan output yang dihasilkan berupa laporan hasil audit yang digunakan oleh Direktur Utama dan Dewan Komisaris untuk menindak lanjuti temuan SKAI Bank SulutGo dengan memberikan sanksi terhadap pegawai terkait berupa PHK, Non Job dan Demosi/penurunan pangkat. Selain memberikan kelebihan, penggunaan EDP juga memiliki kekurangan, yaitu:

1. Program yang akan digunakan dalam EDP umumnya berbayar dan harus diperpanjang secara berkala sehingga memerlukan pengeluaran rutin.

2. Diperlukan pengetahuan khusus untuk melaksanakan perintah-perintah untuk mengoperasikan software seperti Audit Command Language (ACL).

Dengan adanya kekurangan pada penggunaan EDP dalam proses audit, maka auditor internal Bank SulutGo dalam mengatasi kekurangan tersebut melakukan penganggaran dalam pengeluaran biaya dan software yang dipilih benar-benar dapat membantu dalam mengelola data audit. Kemudian melakukan pelatihan-pelatihan penggunaan software ACL bagi auditor dalam membantu pengolahan data. Tetapi auditor lebih sering menggunakan software Microsoft Excel dari pada software ACL dalam melakukan proses audit EDP. Seharusnya auditor dalam melakukan proses audit harus menggunakan software ACL untuk proses audit EDP karena software tersebut dirancang khusus untuk membantu melakukan proses audit dan Bank SulutGo juga telah mengeluarkan biaya untuk mengikuti program pengembangan kompetensi auditor berupa sosialisasi, pelatihan, workshop, dan seminar yang diselenggarakan oleh OJK, KPK, Lembaga Pengembangan Fraud Auditing, BEI, dan Asosiasi Auditor. Auditor juga melakukan pengendalian internal untuk menciptakan kondisi yang mendukung kelancaran dan ketepatan pelaksanaan tugas dalam organisasi sesuai dengan peraturan yang berlaku dengan demikian dapat membatu manajemen/pemimpin perusahaan dalam mengendalikan kegiatan dan operasional bank agar dapat berjalan secara Ekonomis, Efisien dan Efektif. Prosedur pengendalian internal dalam penggunaan EDP, yaitu:

1. Melakukan pengendalian terhadap akses semua sumber daya yang dipakai dalam audit dari pihak yang tidak berhak dengan cara memberikan password akses terhadap penggunaan sumber daya tersebut agar tidak mudah dicuri dan hilang. 
2. Melakukan pengendalian data dan prosedur pengolahan komputer, mengurangi kemungkinan process error, dan menentukan kelanjutan operasional.

3. Melakukan pengendalian input untuk memastikan kelangsungan pemrosesan data dengan cara:

a. Semua data harus disepakati dan diakui oleh manajemen.

b. Pengendalian dalam mengkonversi data agar data di input dengan benar dan pengkonversian dikerjakan dengan sahih.

c. Pelaksanaan koreksi pada data yang tidak benar.

4. Melakukan pengendalian proses dengan maksud agar memastikan pengolahan pada komputer telah dilakukan seperti yang diinginkan.

5. Melakukan pengendalian terhadap output agar menghasilkan data yang diolah dengan benar dan memastikan bahwa hanya pihak yang berhak saja mendapat hasil pengolahan tersebut. Pengendalian output meliputi:

a. Pelaksanaan rekonsiliasi penjumlahan

b. Perbandingan dengan dokumen sumber

Analisis Risiko Dalam Melakukan Proses Audit Komputerisasi. Dalam melaksanakan proses audit menggunakan EDP tentunya diperhadapkan dengan risiko-risiko seperti:

1. Kesalahan dalam pemrosesan data yang diakibatkan oleh human error. Kesalahan ini muncul akibat kurang penguasaan auditor dalam menggunakan software-software audit maupun kelalaian auditor.

2. Hilangnya data pada komputer/laptop yang diakibatkan oleh permasalahan pada komputer/laptop tersebut.

3. Komputer/laptop yang digunakan untuk pemrosesan data terkena virus.

Untuk mencegah risiko tersebut dalam proses audit menggunakan EDP, maka Bank SulutGo meningkatkan kompetensi para auditor dalam menggunakan software untuk mengolah data audit, melakukan back up data pemrosesan audit secara berkala baik media penyimpanan internal maupun media penyimpanan eksternal, serta menginstal anti virus dan melakukan update secara berkala. Risiko merupakan sesuatu yang tidak dapat dihindari walaupun proses audit telah menggunakan bantuan EDP namun auditor tetap harus menghadapi risiko-risiko tersebut. Risiko terjadi bukan hanya diakibatkan oleh auditor namun risiko dapat timbul dari komputer itu sendiri yang dapat menghambat pengendalian internal perusahaan.

\section{KESIMPULAN DAN SARAN}

\subsection{Kesimpulan}

Setelah melakukan analisis pada hasil penelitian, maka dapat disimpulkan bahwa:

1. Auditor yang menggunakan EDP dalam proses audit adalah auditor yang berusia muda karena auditor yang berusia muda lebih cepat beradaptasi dengan perkembangan teknologi informasi terutama dalam melakukan audit dan pengendalian internal terkomputerisasi.

2. Dampak yang diberikan dalam proses audit yaitu meningkatkan independensi bagi auditor internal, memberikan keakuratan dan kecepatan dalam mengelola data, serta menghasilkan output dari pengolahan data audit yang lebih akurat. Dampak bagi pengendalian internal yaitu membuat auditor melakukan prosedur pengendalian internal setelah menerapkan EDP dalam proses audit untuk meminimalisir kemungkinan kesalahan proses, mengamankan program dan data, serta mengendalikan proses audit untuk memberikan kepastian bahwa audit telah dilaksanakan dengan baik.

3. Risiko penggunaan EDP dalam audit seperti kesalahan dalam pemrosesan data yang diakibatkan oleh human error, kehilangan data yang diakibatkan oleh permasalahan komputer, dan komputer yang digunakan terkena virus. Risiko tersebut dapat dicegah 
dengan meningkatkan kompetensi auditor dalam penggunaan software audit, melakukan back up data audit, dan menginstal anti virus yang terupdate secara berkala.

\subsection{Saran}

Dari hasil penelitian yang telah dilakukan maka penulis menyarankan sebagai berikut:

1. Sebaiknya Satuan Kerja Audit Internal (SKAI) Bank SulutGo terus meningkatkan kompetensi para auditor internal agar dapat menggunakan software audit lebih optimal dan menggunakan software ACL dalam setiap melakukan proses audit terkomputerisasi.

2. Software yang digunakan dalam proses audit selalu diperbaharui setiap kali dirilis software audit versi terbaru agar software yang digunakan selalu terupdate dengan fitur-fitur baru dan perbaikan bug dari software yang digunakan.

3. Bagi peneliti selanjutnya sebaiknya melakukan konsultasi judul yang diangkat terlebih dahulu dengan pihak yang menjadi objek penelitian untuk menyamakan judul dengan kondisi di perusahaan dan membuat janji jauh-jauh hari sebelum melakukan wawancara dikarenakan informan harus melakukan audit di kantor-kantor cabang sehingga ketersediaan waktu yang minim.

\section{DAFTAR PUSTAKA}

Amanda, N. S. 2016. Dampak Electronic Data Processing Pada Proses Auditing Dan Pengendalian Internal Bank Bri Wilayah Surabaya. Skripsi. Sekolah Tinggi Ilmu Ekonomi Perbanas. Surabaya.

Hadi, A. M. 2010. EDP Audit (Praktek Tehnik Audit Berbantuan Komputer dengan Aplikasi MS.Excel dan ACL). Erlangga. Jakarta.

Hery. 2013. Auditing (Pemeriksaan Akuntansi 1). Cetakan Pertama. CAPS (Center of Academic Publishing Service). Jakarta.

Ikatan Bankir Indonesia. 2014. Memahami Audit Intern Bank. Edisi 1. PT. Gramedia Pustaka Utama. Jakarta.

Karamoy, H., H. R. N. Wokas. 2015. Pengaruh Independensi Dan Profesionalisme, Dalam Mendeteksi Fraud Pada Auditor Internal Provinsi Sulawesi Utara. Jurnal Riset Akuntansi Dan Auditing "Goodwill" 6(2): 22-31.

Jasmat. 2010. Analisis Penerapan Electronic Data Processing (EDP) Dalam Sistem Informasi Akuntansi Pada Pt. Citra Riau Sarana Kabupaten Kuantan Singingi. Skripsi. Universitas Islam Negeri Sultan Syarif Kasim Riau. Pekanbaru.

Madcoms. 2015. Komputer Akuntansi Dengan MYOB AccountRight Premier. Edisi 1. ANDI. Yogyakarta.

Mardiasmo. 2014. Akuntansi Keuangan Dasar. Edisi 3. BPFE. Yogyakarta

Seputra, Y. E. A. 2013. Belajar Tuntas Audit Berbantuan Komputer. Gaya Media. Yogyakarta.

Sugiyono. 2014. Metode Penelitian Kuantitatif, Kualitatif dan R\&D. Alfabeta. Bandung.

Warren, C. S., Reeve, J. M., dan Buchac, J. 2017. Financial Accounting. Cengage Learning. Kanada.

Yang, M. H., Wen, S. L., Tian, L. K. 2011. The Impact Of Computerized Internal Controls Adaptation On Operating Performance. African Journal of Business Management 5(20): 8204-8214. 